\title{
AZORÍN Y LA SENSIBILIDAD SIMBOLISTA
}

\author{
Miguel Ángel LOZANO MARCO \\ Universidad de Alicante
}

Indagar sobre la presencia del espíritu simbolista en España nos obliga a realizar una nueva reflexión sobre el sentido y las condiciones de la literatura y del arte en un periodo denso, dinámico y fecundo, lo que permite contemplar desde una nueva luz, más fascinante, obras que solíamos entender como de menor alcance y calado, restringidas a un cerrado horizonte nacional. No suele ser considerado Azorín un simbolista, y debo precisar que la finalidad de este breve ensayo no es la de proponer, ni la de justificar, la aplicación de este calificativo; pero creo que su arte se entiende mejor cuando se le sitúa en el ambiente espiritual y estético en el que el escritor fue gestando su obra, y del que captó, con su fina sensibilidad, aquellos aspectos adecuados a su manera de sentir y de pensar. José Martínez Ruiz fue un hombre especialmente sensible, y pronto a impresionarse por las atmósferas espirituales, por los ambientes sugestivos que percibe. Tengamos en cuenta sus criterios, expresados en un par de citas elocuentes: «Lo de menos son los documentos en que se exponga la doctrina innovadora. Lo importante es el ambiente espiritual que se va creando» (1927). Pocos días después, declara a un periodista: «Para mí lo interesante es el ambiente espiritual que me rodea» (Sánchez Ocaña 1927); ambiente que recoge su sensibilidad creado$\mathrm{ra}^{1}$, y que él identifica en lecturas que suscitan «estados de conciencia artística» y lo predisponen para la creación. Las influencias -reitera en diversos lugares- no son imitaciones; son, ante todo, experiencias estimulantes, necesarias para el

' Recordemos que en el texto preliminar a Lecturas españolas [1912] escribía el autor: «La coherencia [del volumen] estriba en una curiosidad por lo que constituye el ambiente español» (1998 II, pág. 696). 
conocimiento de sí mismo, para el descubrimiento de las propias potencialidades, y alientan la creación personal ${ }^{2}$.

Conviene aclarar que, cuando hablamos aquí de Simbolismo, lo entendemos, no como una escuela, un movimiento o una práctica poética relacionada con el «manifiesto» de Moréas o con Mallarmé y su cenáculo, sino como un amplio espíritu de época, común en la cultura occidental, que viene a desarrollarse en plenitud durante los últimos veinte años del siglo XIX y los primeros lustros del que acabamos de dejar atrás. El sentido es el que Michael Gibson apunta en el comienzo de su amplio panorama: «Cuando el Simbolismo hizo su aparición a mediados del pasado siglo, era menos un movimiento artístico o un estilo que una expresión del espíritu» (1999, pág. 7). Suele situarse su desaparición en los años de la Gran Guerra; aunque en nuestro país encontramos muestras en fechas muy posteriores, tanto en pintura como en literatura. Este espíritu simbolista se manifiesta en el arte europeo en obras diversas, y aun de tono y sentido opuesto: comprende desde el idealismo ensoñador y esteticista hasta la revelación inquietante o la visión terrible. El término «simbolismo» se aplica tanto a la creación de Gustave Moreau, Alphonse Osbert o Puvis de Chavannes, como a la de Léon Spilliaert, James Ensor o Edvard Munch: desde lánguidas doncellas prerrafaelitas o visiones ideales de la mitología, hasta una plástica revelación tan terrible como la de ese cuadro, «El grito», que atraviesa todo un siglo sin perder su intensidad, y que todavía atruena en nuestro interior como una obsesión.

No hay, pues, uniformidad simbolista; hay, en un principio, una negación y un rechazo: rechazo del naturalismo y del arte burgués, hastío por la vulgaridad, el prosaísmo y el materialismo de una época en la que el artista ha tenido la desdicha de nacer. Es, ante todo, una protesta contra el utilitarismo, contra las consecuencias de la sociedad industrial $l^{3}$, contra la cosificación a la que ha quedado

2 Pueden leerse, entre otros, dos textos esclarecedores, separados por un considerable número de años: el artículo «Las influencias literarias» (1911), y el capítulo titulado también «Las influencias literarias» de su libro de 1941 Madrid : «La influencia debemos aceptarla, principalmente, como un estimulante para la creación. Sea o no sea exacta la idea que tenemos de nuestro autor, el autor que nos interesa, que nos entusiasma, ese autor influirá en nuestro trabajo. Y acaso influya más si la idea es falsa. Porque entonces somos nosotros los que creamos ese autor, lo creamos para nuestro caso, y escribimos la obra con arreglo a lo que deseamos» (1998 II, págs. 952-953).

${ }^{3}$ Constituye todo esto un asunto importante en Diario de un enfermo (1901), la primera novela de Martínez Ruiz: «Hay una barbarie más hórrida que la barbarie antigua: el industrialismo moderno, el afán de lucro, la explotación colectiva en empresas ferroviarias y bancarias, el sujetamiento insensible, en la calle, en el café, en el teatro, al mercader prepotente» (1998 I, pág. 179). Es, también, lo que apreciaba Eduardo L. Chavarri en su artículo de 1902, ganador en el concurso de Gente Vieja, recogido por Lily Litvak (1975, págs, 21-27): «No es precisamente [el modernismo] una reacción contra el naturalismo, sino contra el espíritu utilitario de la época, contra la brutal indiferencia 
reducido el ser humano; y esto lo hace más cercano a nuestra sensibilidad actual: esa mezcla de malestar y de fatal resignación ante una concepción del hombre valorado como factor de producción y de consumo y medido por los resultados del éxito personal. El simbolista es un arte de sentido trascendente: reivindica la esencia trascendente del ser humano, y tal vez viene a ser la despedida de esa visión del hombre en los umbrales de un siglo cruel, violento y sanguinario.

El simbolismo es también una afirmación: un arte de sugerencias, centrado en el laboreo sobre las sensaciones, dedicado a bucear en el yo íntimo o en las relaciones del alma con el mundo, orientado hacia una visión analógica del universo, atento a percibir las correspondencias sutiles entre las cosas. Y es, ante todo, un entendimiento del lenguaje como símbolo, y no como signo: la palabra rebosa sentidos al tiempo que se potencia las sugerencias que hay en su propio sonido, al margen del significado convencional. Se rechaza lo puramente referencial, lo denotativo, para insistir en lo connotativo y en lo sugestivo.

Conviene partir de un par de definiciones adecuadas al asunto que desarrollamos. Acudamos en primer lugar a un libro clásico, el de Marcel Raymond, De Baudelaire au surréalisme, donde el investigador identifica y resume aquello que da unidad al gran número de tendencias amparadas por el término «simbolismo»: «Una poesía que intenta expresar 'el alma de las cosas' y los movimientos de la vida profunda, y un poeta que quería 'sugerir el misterio'» (1960, pág. 47). Entre sus varias direcciones, encontramos también la presencia del ocultismo, el espiritismo..., etc. A Ricardo Gullón debemos la definición más sucinta: «El simbolismo, más que una escuela, es manera de creación caracterizada por la sugestión $y$, a veces, por el hermetismo $»^{4}$. El segundo elemento no es constante; lo sustantivo es lo primero: un arte de sugerencias.

Como bien sabemos, no encontramos a Azorín formando entre los simbolistas, porque ni él se declara así, ni existe en los manuales de historia de la literatura española un capítulo encabezado por tal rótulo; y es que en España casi nadie se califica de ese modo. Sin embargo, Juan Ramón Jiménez en los años cincuenta no se cansa de repetir que él es simbolista; que el modernismo es simbolismo; que Unamuno y Machado son simbolistas... ${ }^{5}$ A comienzos de siglo, sólo el

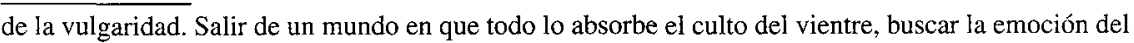
arte que vivifique nuestros espíritus fatigados en la violenta lucha por la vida, restituir al sentimiento lo que le roba la ralea de egoístas que domina en todas partes...»

${ }_{4}^{4}$ Simbolismo y modernismo», recogido por J. Olivio Jiménez, ed., (1979, pág. 21$)$.

${ }^{5}$ Véase como reitera la afirmación en las opiniones recogidas por Ricardo Gullón en su libro Conversaciones con Juan Ramón Jiménez (1958), y los criterios expresados a lo largo de su curso de 1953, editado de nuevo con amplio aparato crítico por Jorge Urrutia (1999). 
grupo de Helios viene a presentarse de manera explícita como influido por esa estética, pero sin hacer hincapié en el término ${ }^{6}$.

Lo cierto es que Azorín nunca se relaciona, vincula o integra en un ismo, salvo en una época, a finales de la década de los años veinte, cuando se acoge a un peculiar «superrealismo» (traduciendo de manera correcta el término francés surréalisme). Lo que de verdad está claro es que Azorín no es un surrealista: no practica el automatismo psíquico -la escritura automática al margen de la vigilancia de la razón y ajeno a toda preocupación estética o moral-, ni bucea en el inconsciente, ni lo intenta sorprender en los sueños. El escritor levantino entiende como «superrealista» todo aquel arte que supera el realismo y el naturalismo: un arte poético de lo sutil, que indaga en el misterio y que da forma a una nueva realidad superior. Un fragmento de su obra de 1929 Superrealismo (Prenovela) puede ser muy elocuente; en el capítulo 46, «Luna» (1998 I, págs. 939-940), leemos:

El misterio de las cámaras en que entra un rayo de luna vaporosa, acaso más impresionante que la noche oscura. Los olores de la noche; la correspondencia misteriosa entre la luna y las cosas y los hombres. [...] Talismán de luna; talismán en que vaya condensado todo este ambiente de misterio, de poesía, de anhelo hacia lo infinito, que respiramos en las claras, radiantes, noches de luna. En las noches en que, despiertos por acaso, vemos cómo un suave, acariciador, sedoso rayo de luna, cautelosamente, ha entrado por la ventana que se ha quedado abierta e ilumina la estancia y envuelve en cendales los muebles. $\mathrm{Y}$ ante tanta suavidad y dulzura, no nos sentimos tranquilos; un ligero estremecimiento nos conmueve. Y pensamos en una región infinita, que no podemos concebir, y en que sólo vemos ahora una infinita claridad de luna.

Misterio, poesía, sensaciones delicadas y etéreas, visión fascinante bajo una luz que es a un tiempo real e irreal, natural y sobrenatural. Belleza visual y eufonía en el lenguaje. Sensaciones, sugerencias... Nada de escritura automática ni de buceo en el inconsciente. Hay una fascinación por la visión concreta de algo sutil, y una concepción analógica del cosmos en esa intuición del infinito en las imágenes el mundo. De lo concreto de la experiencia al ensueño (no al «sueño») y a la intuición de lo infinito y de lo eterno: puro simbolismo, esencializado, depurado, como no podía ser de otro modo en una época de «purismo poético»: simbolismo estilizado (Lozano Marco 2001). «Poesía irreductible» llamaba Azorín a la poesía pura (1929), en cuyo contexto temporal «depura» Azorín su prosa: la prosa

'Patricia O'Riordan (1970, págs. 57-150). Ignacio Prat (1978, pág. XL) estimaba que las colaboraciones de Rubén Darío, Antonio Machado y Marquina con las que se inicia el libro de Gregorio Martínez Sierra La casa de la primavera (1907), «convirtieron al poemario en la brotherhood simbolista española». 
de Superrealismo o de Pueblo (1930), obra dedicada a Jorge Guillén, a la que quiso subtitular «novela pura».

No encontramos textos en los que de manera directa, explícita, se adhiera al simbolismo, o se afirme como simbolista -aunque sí lo hace de manera indirecta, como veremos-. Lo que encontramos son algunas descalificaciones o críticas adversas tanto al simbolismo como al modernismo. Aislando estos textos, e influidos por ciertos prejuicios derivados de la idea de «generación del 98», veríamos en Azorín a un antimodernista. Y en este sentido han abundado las lecturas parciales y defectuosas. Al modernismo sólo dedicó el levantino un artículo: en 1908, el titulado «Romanticismo, modernismo». En él estima que «el modernismo ha sido un movimiento sin trascendencia alguna y sin hondura». Su duración «no ha pasado de cuatro o seis años». No ha sido más que una «alharaca verbal» (por el empleo de palabras ridículas y afectadas), cuyo fondo «era el antiguo fondo sentimental y plañidero de nuestros abuelos». «Con tal procedimiento lo que se ha logrado es separar al público de la obra de arte, distanciar al lector medio de la belleza»? Leamos bien: no acusa al modernismo de esteticista, frente a un arte comprometido que lucha por algo (J. Martínez Ruiz abandonó esta concepción del arte alrededor de $1898^{8}$ ); lo acusa de fraude estético.

Todo en ese texto de 1908 es impreciso: imprecisa la duración de tal movimiento (cuatro o seis años; pero, ¿desde cuándo hasta cuándo?), y aún es más impreciso por la ausencia de cualquier nombre representativo. Azorín no entendía el modernismo como después lo ha entendido la crítica, sino como él lo había vivido en la calle. Modernista era un término despectivo que venía a significar extravagante, ridículo, melenudo, anarquista, bohemio, y, como recuerda Baroja (1982, pág. 13), «modernista y esteta eran palabras sinónimas de pederasta». El modernista era el mal poeta, el bohemio ridículo que inspiraba burlas". Se entiende así que Azorín no gustara de que lo calificaran de ese modo.

Pero lo cierto (frente a lo incierto anterior) es que Azorín elogió con verdadera admiración y desde sus primeros libros a Juan Ramón Jiménez, Antonio Machado, Enrique de Mesa, Enrique Díez Canedo, Ramón Pérez de Ayala, e incluso incorporó a la nómina poética al mismo Francisco Villaespesa ${ }^{10}$; y, como

'ABC, 3 de agosto de 1908; recogido por José García Mercadal (Azorín 1952, págs. 289-291).

${ }^{8}$ Véase su panfleto de 1898 Pecuchet, demagogo, y confróntese con la postura que adopta en el libro siguiente: La evolución de la crítica (1899).

'Véase el capítulo «El poeta sin nombre», de su libro Madrid (1998, págs. 1005-1006).

"En este sentido, es importante su artículo «Dos generaciones» (1910). 
es bien sabido, vio en Rubén Darío al representante de la nueva poesía (1905 b), y hasta lo incluyó en la nómina de la «generación del 98», en los famosos artículos de 1913. Éstos son los modernistas, aunque nunca los llama así; cuando se refiere a ellos, los menciona en grupo como los «novísimos»; es decir, los herederos y continuadores de la nueva literatura, de la que él era un representante en la creación y en la crítica. Pues bien, estos modernistas son precisamente aquéllos entre los que predomina el espíritu simbolista.

Para todo lo relacionado más directamente con su actitud ante el simbolismo tenemos que acudir a textos de hacia 1898. En algunos se muestra aparentemente contrario. Remito a mi artículo «J. Martínez Ruiz en el 98 y la estética de Azorín» (Lozano Marco 1997), donde fui siguiendo en una sucesión de datos concretos, desde 1893 hasta 1905, la formación de su arte; pero es necesario recordar dos citas elocuentes que hemos de entender sin prejuicios. La primera se encuentra en un contexto de defensa del arte social: «No niego que en algunos de esos literatos simbolistas hay algo de revolucionario, y lo hay; pero ¿por qué escribir en esa forma oscura? ¿Por qué obstinarse en hacer incomprensible lo que puede ser claro como la luz?» (1897). La segunda la encontramos un año después, dentro de una polémica con Tullio Hermill -seudónimo del periodista catalán Juan Pérez Jorba-, y matiza el contenido de la anterior: «Si Maeterlinck, Verlaine, Barrés, D'Annunzio..., son universales, no es ciertamente por sus excentricidades, por sus refinamientos obscenos, por sus galimatías poéticos o filosóficos; lo son por aquella parte de su obra sana y radiante» (1898a). Si entendemos bien, lo que censura es la oscuridad, lo excéntrico, lo abstruso, lo «raro y exquisito» buscado con pedantería; porque estima que ese mismo arte simbolista puede ser «claro como la luz», y en esto va a radicar su original aportación.

El modelo inspirador lo encuentra muy pronto. El escritor levantino establece una diferencia y manifiesta una preferencia que ya en 1896 había dado como resultado su traducción de La intrusa de Maeterlinck, precedida por un breve y elocuente prólogo. Resulta curioso que un joven ácrata, que se había manifestado partidario del naturalismo y de un arte concebido como vanguardia de la revolución, se tome el trabajo de traducir un drama simbolista, dedicado a las minorías. Pero en esta obra encontramos el primer germen del arte más representativo del futuro Azorín, el que ha de cultivar a lo largo de muchos años, siguiendo siempre la evolución de los tiempos. El joven escritor percibe por vez primera una literatura que muestra el misterio en la vida cotidiana, entre conversaciones vulgares y objetos de nuestra común experiencia. En el prólogo a su traducción resume Martínez Ruiz el ambiente y el sutil movimiento de la casi inexistente acción: 
...Es un drama simbolista. La intrusa es la muerte: Ias rosas que se deshojan, los ruiseñores que vuelan espantados, los cisnes que tienen miedo, el perro que se arrincona en su garita... indican su paso por el jardín. Después penetra en la casa, siéntese un momento en la sala donde está la familia, y se mete por fin en el cuarto de la enferma. Es un caso de sugestión. La vulgaridad del diálogo, las repeticiones enojosas, la calma siniestra de la escena, llegan a producir en el espectador una verdadera obsesión. [En esta obra] no son sốlo personajes todos los que hablan, lo son también el ruido de la hoz, la puerta que no quiere cerrarse, el rayo de luna que pasa a través de los cristales verdes, la luz de la lámpara que oscila y se apaga. Se trata de un drama psicológico; pero su psicología no es exclusivamente humana, sino de la naturaleza toda".

En Maeterlinck ha encontrado el punto de partida para desarrollar un arte que es consustancial a él; pues es cierto que, siguiendo sus propios criterios, lo que llamamos «influencias» son en realidad sugestiones, hallazgos del propio sentir, descubrimiento de las vastas regiones de uno mismo. Azorín encontró en el simbolismo un medio de expresión artística que podía ser «claro como la luz», y en ello insistió. Recordemos en este punto la definición tan sucinta de Ricardo Gullón: el simbolismo, «más que una escuela, es una manera de creación caracterizada por la sugestión y, a veces, por el hermetismo». Azorín prescinde de lo hermético, lo rechaza para conducir las sugestiones hacia el ámbito de lo cotidiano, para apreciar la belleza y el misterio en lo vulgar y lo anodino. Recoge lo sustancial y elimina lo adjetivo.

Lo que encontró en La intrusa lo percibimos en muchos textos, en los que se advierte la presencia evanescente del misterio: en Los pueblos, libro atravesado por el invisible aliento de la muerte; en piezas como «Una familia» (Lecturas españolas), cuyo personaje central es una persona ausente evocada por todos (Lozano Marco 2000), o en la trilogía de Lo invisible (1929), una especie de adaptación de La intrusa al ambiente poético de los años veinte; pero también se puede vincular el hallazgo de esta visión poética de lo vulgar y cotidiano con la manera de leer ciertos libros en los que encuentra un estímulo para su creación. Los Diálogos latinos de Juan Luis Vives, obra escrita por el humanista valenciano como ejercicios para la enseñanza de la lengua latina, es entendida por Azorín como una obra dedicada a suscitar visiones limpias de la vida cotidiana más anodina, y de ahí su belleza. Vives ha sentido «la eterna poesía de lo pequeño y coti-

"Mauricio Maeterlinck (1896). Conviene apuntar que Azorín utiliza el término «psicológico» [«drama psicológico» o psicología de la naturaleza] con un sentido etimológico: «aquello que trata sobre el alma»; del mismo modo que cuando habla de la «crítica psicológica», la que él propone, se está refiriendo a la que revela «el espíritu del libro»; se trata, pues, de una manera «simbolista» de leer. 
diano»; en ese libro podemos ver «cómo pasa la existencia menuda y prosaica de los pueblos en una serie de pequeños cuadros auténticos»; de este modo su autor «llegó inconscientemente hasta el nexo secreto de la vida» y puede revelar «la armonía que en nuestra existencia diaria forman los detalles y los objetos menudos» ${ }^{12}$. Muchos años después, en 1943, al hablar de sus novelas, esas novelas en las que no pasa nada, reitera el espíritu de lo apuntado en el inicio del siglo: «Había una medula en la vida, independiente de la acción, y era preciso extraerla [...] Si se llegaba a lo de dentro, ¿para qué se quería lo de fuera?» (1.998 III, pág. 1061).

Con el precedente de su fascinación ante Maeterlinck, lo que es revelador de su sensibilidad melancólica y ensoñadora, es necesario insistir en la importancia fundamental de un artículo de 1898 , «Un poeta», un texto de valor estructural en su estética, puesto que lo que allí afirma lo encontramos a lo largo de toda su obra, en diferentes lugares y bajo diversas modalidades. En este artículo (1898b), dedicado en principio a Vicente Medina, introduce de repente una reflexión estética y una confesión: al hablar de «el alma de las cosas» cita a los grandes artistas: Verlaine, Maeterlinck, Rodenbach, y a continuación se extiende recordando la emoción extraordinaria que le produjo la lectura de La intrusa: el ambiente de tristeza, la conversación vulgar, la invisible presencia de la muerte, el lenguaje de las cosas que hace vibrar el alma: «Hablan las cosas: hablan las hojas de los árboles del jardín, la puerta que no quiere cerrarse, el rayo de luna que atraviesa las vidrieras multicolores, la lámpara que se apaga lentamente, el grito del niño que llora...» Y termina haciendo profesión de fe en el «alma de las cosas»: «tiene alma cuanto nos rodea, cuanto vive a nuestro lado y asiste a nuestras tragedias íntimas, a nuestros dolores microscópicos, a nuestras expansiones de placer, a nuestras alegrías de una hora».

Este texto de 1898 es el primero en el que podemos comprobar que el principal estímulo poético, dentro de un «espíritu simbolista», procede principalmente del simbolismo belga, de enorme presencia entre los escritores españoles finiseculares (Mechthild Albert 1992). Maeterlinck es la gran figura en los primeros años del siglo, y Georges Rodenbach, hoy casi olvidado, es el poeta que ocupa un primer lugar en revistas y antologías poéticas: es el poeta de la melancolía provinciana, de las ciudades muertas, de la tristeza de los domingos; el poeta del silencio, de los atardeceres tristes, de la vida doméstica apagada, del alma de los muebles familiares, de la sugestión que produce cuanto nos rodea... Para

12 «Filósofos españoles: Vives» (Azorín 1903). Este breve texto lo recogió en 1912 para abrir con él su libro Lecturas españolas. 
Martínez Ruiz, Rodenbach se convierte en el modelo del artista que sabe recoger los matices de las cosas $\left(1898 \mathrm{c}\right.$ y $1900 \mathrm{~b}$ ) ${ }^{13}$. Como expuse en otro lugar (Lozano Marco 1997), el simbolismo belga se diferencia del francés, principalmente, por su acercamiento al mundo germánico (situándose en lo que Robert Rosenblum (1993) ha denominado la «tradición del romanticismo nórdico»), y por sentirse «periférico» con respecto a la metrópolis ${ }^{14}$. Frente a lo propuesto en el conocido Manifiesto del Simbolismo de Jean Moreas, publicado en septiembre 1886 ( $\ll$ La poesía simbólica intenta vestir la idea con una forma sensible»), lo que viene a definir un procedimiento alegórico, o frente a lo expresado por Mallarmé («Nombrar un objeto es suprimir las tres cuartas partes del goce del poema...; el propósito es sugerirlo»), Verhaeren en abril de 1897 delata la confusión entre símbolo y alegoría para afirmar que «se parte de la cosa vista, oída, sentida, tocada, gustada, para hacer nacer la evocación y el resumen por la idea». «El símbolo se depura siempre, a través de una evocación, en idea: es un sublimado de percepciones y sensaciones; no es demostrativo, sino sugestivo» (Verhaeren 1887). Los simbolistas belgas parten siempre de las imágenes del mundo. No rehuyen nombrar el objeto: lo nombran para acceder desde esas imágenes del mundo a una realidad superior ${ }^{15}$. A propósito de la diferenciación apuntada, recordemos cómo, en 1902, Eduardo L. Chávarri encontraba en el modernismo «dos grandes formas: una que proviene de su origen y de su desenvolvimiento en los países del Norte de Europa, y otra que nace principalmente en París. Es algo semejante a lo que ocurrió con el primer gran vuelo romántico: una dirección hacia el espíritu y otra hacia la forma exterior más o menos ornamental» (Litvak 1975, pág. 24).

Los autores simbolistas que impresionaron la sensibilidad del joven Martínez Ruiz son los más afincados en el mundo cotidiano, en los ambientes en

${ }^{13}$ El cultivo del matiz es tarea artística que Azorín perseguirá a lo largo de su obra, como lo revela en novelas tan distantes como Diario de un enfermo [1901] o La isla sin aurora [1944]. En la primera leemos: «Como antes no supieron comprender la naturaleza, ni acertaron con la poesía del paisaje, ahora no comprendemos lo artístico de los matices de las cosas, la estética del reposo, lo profundo de un gesto apenas esbozado [...] ¿Cómo traducir los mil matices, los infinitos cambiantes, las innumerables expresiones del silencio?» (1998 I, págs. 181-182); y en la novela de 1944 leemos: «el arte es la captación y gradación de los matices» (1898 I, pág. 1298).

${ }^{14}$ Es muy interesante para entender este sentimiento de artista «periférico» la novela de Georges Rodenbach, L'art en exil (1889).

is El profesor Michel Otten estima que la poesía de los simbolistas belgas, comparada con la de sus contemporáneos franceses (Régnier, Kahn, Stuart Merrill), parece más concreta, más visual y plástica; y continúa: «Il est certain que les Français abusent des images emblemátiques, allégoriques, situées dans un espace-temps mythique [...]. C'est plutôt le monde réel, proche, que capten nos Symbolistes» (Otten 1986, pág. 207). 
los que vivían (las pequeñas capitales provincianas de un país periférico), los menos abstractos, los más cercanos a las cosas concretas percibidas desde una nueva luz y con una nueva finalidad: intuir lo infinito en las imágenes del mundo, algo que constituirá un fundamento estético en Azorín a lo largo de toda su obra, como hemos podido apreciar en la cita del capítulo «Luna», y como lo podemos comprobar tanto en su última novela, Salvadora de Olbena [1944], como en el libro más revelador de su totalidad creadora, Memorias inmemoriales [19431946].

A la sugestión simbolista (de procedencia belga, principalmente), hay que añadir la conciencia que Martínez Ruiz manifiesta de encontrarse en una nueva época, con una nueva sensibilidad: «la evolución de la sensibilidad» es una de las convicciones permanentes de Azorín ${ }^{16}$ : una evolución positiva que es el más firme cimiento para el progreso humano. Esa nueva y más rica sensibilidad se percibe en un nuevo uso del lenguaje, que sería incomprensible para los antiguos. En 1900 , al final de Los hidalgos expresa su convencimiento de estar operando con un nuevo lenguaje, producto de una nueva sensibilidad, que propicia un nuevo arte:

El idioma todo parece renovado. Por otra parte la sensibilidad del hombre moderno es mayor, y créanse por consiguiente giros, expresiones, modos de decir no usados de los antiguos. Acrécese la sensación, y acrece paralelamente la forma en que la sensación ha de ser traducida. Hay en el lenguaje actual matices, delicadezas, cambiantes desconocidos de las generaciones pasadas. Nada acusa tan notablemente el progreso de la humanidad como los medios de exteriorización. Acaso los hombres del siglo XVI no entendieran una novela analítica de estos tiempos. $\mathrm{Y}$ acaso nos veríamos precisados a emplear prolijas explicaciones para comunicarles estados psicológicos que hoy cambiamos entre nosotros sin palabras... (1900, págs. 68-69).

El arte de Azorín se fundamenta en la percepción y en la expresión de las sensaciones: desde su «leitmotiv» de La voluntad («la sensación crea la conciencia, la conciencia crea el mundo») hasta sus últimos textos. En 1959, en su libro Posdata, nos viene a decir que es necesario tener mucha imaginación para escribir una novela en la que no pasa nada: «Lo estático puede ser tan novelesco como lo dinámico. La sensación puede darse con más intensidad» (1959, págs. 51-52). Azorín es maestro en la expresión de las sensaciones que le producen los lugares, las lecturas, los interiores, las horas del día... «Hubiera querido yo ahincar más en las cosas y en sus emanaciones, o sea la sensación», dice en Memorias inmemo-

\footnotetext{
${ }^{16}$ Véase el importante artículo del mismo título recogido en el libro Clásicos y modernos.
} 
riales (1998 III, pág. 1160); pero lo cierto es que nunca lo ha dejado de hacer: «por los sentidos entra en nosotros el mundo. $Y$ de las sensaciones saltamos, como ahora en la noche estrellada, a lo que no puede expresarse, a lo Infinito» (1998 III, pág. 1161). También es así como valora la excelencia de un escritor: el mejor prosista -dice- no es el de mayor riqueza léxica, «sino quien ha hecho expresar a la prosa mayor número de sensaciones y más intensas» (1998 II, pág. 879).

Suele vincularse la estética simbolista con la poesía lírica, exclusivamente. Pues bien, Azorín escribe en 1905 un artículo titulado «La nueva poesía», en el que rechaza la vieja separación entre prosa y verso. Estima que no hay procedimientos propios del verso que no puedan emplearse igualmente en la prosa; y aún más cuando la nueva poesía no se fundamenta en procedimientos retóricos, sino en la «psicología». La nueva poesía la encuentra en Rubén Darío, y su propósito es manifestar una sensación eliminando detalles para destacar «únicamente el sugestivo, el representativo, el que presta a la cosa su esencia» (1905b). Entendamos bien: lo que destaca no es lo representativo del objeto, sino lo representativo de la sugestión que tal objeto produce; y ejemplifica con un verso de «La dulzura del Ángelus»: « $i$ Oh suaves campanas entre la madrugada!»: «Y estas breves palabras, acaban de imbuirnos la sensación intensa, trágica, misteriosa, de un mundo de luces y de sombras que se abren un momento para nosotros».

Azorín, poeta en prosa, aprendió desde muy joven en el padre del simbolismo y de la poesía moderna, Baudelaire, cuyos Pequeños poemas en prosa son sus modelos constantes; y también leyó la obra de Huysmans, À rebours, donde se propugna como ideal literario el poema en prosa. Y Azorín es «acaso el mayor y más abundante poeta en prosa de nuestra literatura», como apuntara Jaime Gil de Biedma (1994, pág. 330).

Con todo lo expuesto debemos referirnos necesariamente a lo que pudiera ser su «manifiesto», el artículo «Confesión de un autor» (publicado a comienzos de 1905 con motivo de la aparición de su libro Los pueblos $)^{17}$, que viene a ser expresión del «espíritu simbolista» tal como lo propone el escritor, y tal como lo va manifestando en sus escritos: la atención a los objetos y sucesos vulgares y la intuición del misterio; la belleza de lo vulgar y el concierto de las cosas cotidianas entendido como una revelación de lo eterno. La «fuerza misteriosa del Universo» se nos aparece revelada con nueva belleza en un «nuevo arte» que es

${ }^{17}$ El artículo aparece en el diario España el día 6 de febrero de 1905. Sobre este texto fundàmental véase mi breve ensayo «Un peculiar manifiesto: «Confesión de un autor». Azorín y el 'nuevo arte'» (1999). 
el resultado de ensamblar armónicamente sucesos insignificantes, objetos vulgares y vidas opacas. Es una nueva manera de sentir nuestra cotidiana vida ${ }^{18}$, de atender a la conciencia de nuestro lugar en las circunstancias: no se trata de que veamos o sintamos determinada cosa, sino de que tengamos conciencia de que estamos viendo o sintiendo esa cosa; lo referencial no es el objeto o la acción que sucede en el mundo exterior, sino lo que sucede en nosotros: la conciencia de nuestro yo en una circunstancia, y la estrecha relación identificativa que se establece entre nuestro yo y el mundo. Es la fascinación ante lo vulgar, lo anodino: nos sorprendemos viviendo con lo que nos rodea y en lo que nos rodea. En las experiencias más cotidianas e irrelevantes, en el momento de silencio que se produce en medio de una conversación, en una tertulia nocturna de invierno, se hace presente una sencilla revelación del mundo:

Fuera, en la calle, retumban de rato en rato los pasos precipitados, sonoros, de un transeúnte. Estos pasos que oímos de noche, en la soledad, en el silencio, tienen un ruido extraño. Las calles están oscuras, desiertas; acaso allá, en la remota lejanía, se oye la voz plañidera, larga, de un sereno; tal vez -si estas viejas ciudades tienen ferrocarril- se percibe también el silbato apagado, imperceptible, de una locomotora. Y entonces, de todos estos ruidos -los pasos, la voz, el silbido, el golpecito de la ventana, el crujir de los troncos de la chimenea, los picotazos rítmicos de las perdices-, entonces, de todo esto se forma como una síntesis suprema, como un coro profundo, misterioso, que es la voz eterna, incomprendida de las cosas (1998 II, págs. 380-381).

Recordemos de nuevo la caracterización general del simbolismo según Marcel Raymond: el escritor, el poeta «intenta expresar el alma de las cosas, los movimientos de la vida profunda, y sugerir el misterio». Azorín logra con simplicidad, con claridad, eliminar el hermetismo y percibir el alma en los objetos más vulgares, en las circunstancias cotidianas y en las vidas opacas. «El alma de las cosas» es un sintagma que el escritor reitera en los primeros años del siglo; pero también lo encontramos en sus últimos escritos: «Se suele hablar de las novelas en que no pasa nada; en esas novelas es, precisamente, donde pasan más cosas. La intensidad suple al enredo: en un estado de contemplación, la sensibilidad, con hondo impulso, se aúna con el alma del mundo» (Azorín 1944). Y aquí todo logra su coherencia: sólo la sensibilidad puede intuir el alma del mundo y su irradiación en el alma de las cosas. Azorín percibe y expresa sugerencias, sugestiones, analogías, correspondencias armónicas entre los datos que nos aportan los sentidos. En resumen: logra expresar el misterio de lo que nos rodea, y el miste-

${ }^{18}$ Se trata de esa «nueva manera de mirar las cosas» a la que el profesor E. Inman Fox se ha referido en varios lugares ( Fox 1999). 
rio que es nuestra propia existencia, desde una sensibilidad simbolista. Una sensibilidad que capta la más imperceptible vida; la de las puertas, por ejemplo: «Una puerta no es igual a otra nunca: fijaos bien. Cada una tiene su vida propia: Hablan con sus chirridos suaves o broncos; tienen sus cóleras que estallan en recios golpes; gimen y se expresan, en las largas noches de invierno, en las casas grandes y viejas, con sacudidas y pequeñas detonaciones, cuyo sentido no comprendemos» (Azorín $1998 \mathrm{I}$, pág. 603). Es el misterio de la vida, que al poeta no le cumple desvelar, sino percibir y, sobre todo, expresar.

\section{REFERENCIAS BIBLIOGRÁFICAS}

[Azorín] J. Martínez Ruiz. 1897, «Crónica», El País, 22 de enero; recogido por José María Valverde (1972, págs. 96-103).

- 1898a. «Avisos de Este», El Progreso, 12 de febrero.

- 1898b. «Un poeta», El Progreso, 5 de marzo; recogido por José María Valverde (1972, págs. 152-156).

- 1898c. «Gaceta de Madrid», Madrid Cómico, 26 de marzo.

- 1898d. Pecuchet, demagogo, Madrid, Imprenta de Bernardo Rodríguez.

- 1899. La evolución de la crítica, Madrid, Librería de Fernando Fe.

- 1900a. Los Hidalgos, Madrid, Librería de Fernando Fe.

- 1900b. «Hipérboles», Progreso, 16 de diciembre.

- 1903. «Filósofos españoles: Vives», Los Lunes de El Imparcial, 23 de noviembre.

AzoRín. 1905a. «Confesión de un autor», España, 6 de febrero; recogido en Los pueblos (Ensayos sobre la vida provinciana), Obras selectas, Madrid, Biblioteca Nueva, 1943, y en las diversas ediciones posteriores.

- 1905b. «La nueva poesía», $A B C, 6$ de julio; recogido en Los clásicos redivivos. Los clásicos futuros, Madrid, Espasa-Calpe, 1945.

- 1908. «Romanticismo, Modernismo», $A B C, 3$ de agosto; recogido en $E l$ oasis de los clásicos, Madrid, Biblioteca Nueva, 1952. 
- 1910. «Dos generaciones», $A B C, 18$ de mayo; recogido en Obras completas, IX, Madrid, Ed. Aguilar, 1959, págs. 1136-1140.

- 1911. «Las influencias literarias», $A B C, 13$ de julio.

- 1927. «El superrealismo es un hecho evidente», $A B C, 7$ de abril; recogido en Ante las candilejas, Zaragoza, Librería General, 1947, págs. 112-116.

- 1929. «Tres poetas», La Prensa, 8 de septiembre; recogido en Ultramarinos, Barcelona, E.D.H.A.S.A., 1966, págs. 112-118.

- 1944. «La novelística», Destino, 17 de junio; recogido en Escritores, Madrid, Biblioteca Nueva, 1956, págs. 263-269.

- 1952. El oasis de los clásicos, Madrid, Biblioteca Nueva.

- 1959. Posdata, Madrid, Biblioteca Nueva.

- 1998. Obras Escogidas, t. I: Novela completa; t. II: Ensayos; t. III: Teatro. Cuentos. Memorias. Epistolario, Coordinador: Miguel Ángel Lozano Marco, Madrid, Espasa Calpe.

ALBERT, Mechthild. 1992. «La réception du symbolisme belge en Espagne», Oetuvres et Critiques, XVII, 2, págs. 113-130.

Baroja, Pío. [1945] 1982. Desde la última vuelta del camino. III. Final del siglo XIX y principios del XX, Madrid, Caro Raggio, Editor.

Fox, E. Inman. 1999. «Azorín y la nueva manera de mirar las cosas», Anales Azorinianos, núm. 7, págs. 11-22.

GiBSon, Michael. 1999. El Simbolismo, Köln, Taschen.

GIL DE BIEDMA, Jaime. 1994. «Luis Cernuda y la expresión poética en prosa», El pie de la letra. Ensayos completos, Barcelona, Ed. Crítica.

Gullón, Ricardo. 1958. Conversaciones con Juan Ramón Jiménez, Madrid, Taurus.

- 1979. «Simbolismo y Modernismo», en J. Olivio Jiménez, págs. 21-64.

- 1990. Direcciones del Modernismo, Madrid, Alianza Editorial.

JiMÉNEZ, J. Olivio, ed. 1979. El Simbolismo, Madrid, Taurus. 
JimÉnEZ, Juan Ramón. 1999. El Modernismo. Apuntes de un curso (1953), ed. de Jorge Urrutia, Madrid, Visor.

LiTVAK, Lily, ed. 1975. El Modernismo, Madrid, Taurus.

LOZANo MARCO, Miguel Ángel. 1995. «Algunas consideraciones sobre la estética simbolista en los primeros libros de Azorín (1905-1912)», VV.AA., Azorín et la France, Biarrtiz, J\&D Éditions, págs. 81-91.

- 1996. «Schopenhauer en Azorín. La necesidad de una metafísica», Anales de Literatura Española, Serie Monográfica, núm. 2, Schopenhauer y la creación literaria en España, págs. 203-215.

- 1997. «J. Martínez Ruiz en el 98 y la estética de Azorín», en José-Carlos Mainer y Jordi Gracia, eds., En el 98 (Los nuevos escritores), Madrid, Visor-Fundación Duques de Soria, págs. 109-135.

- 1999. «Un peculiar manifiesto: «Confesión de un autor», Azorín y el nuevo arte», en Ramón F. Llorens y Jesús Pérez Magallón, eds., Luz Vital. Estudios de cultura hispánica en memoria de Victor Ouimette, Alicante, C.A.M.McGill University, págs. 107-112.

- 2000. «La creación artística en Lecturas españolas», en Imágenes del pesimismo. Literatura y arte en España 1898-1930, Alicante, Publicaciones de la Universidad de Alicante, págs. 89-101.

- 2001. «El trabajo oscuro de lo subconsciente. Superrealismo y experiencia en Azorín», en VV.AA., Azorín et le Surréalisme, Gardonne, Éditions Fédérop, págs. 173-184.

MAETERLINCK, Maurice. 1896. La Intrusa, arreglado por J. Martínez Ruiz, Valencia, Imprenta de Francisco Vives Mora.

O'Riordan, Patricia. 1970. «Helios, revista del modernismo (1903-1904)», Ábaco. Estudios sobre literatura española, 4, Madrid, Castalia, págs. 55150 .

OTtEN, Michel. 1986. «Situation du symbolisme en Belgique», Les Lettres Romanes, núms. 3-4, Centenaire du Symbolisme en Belgique, págs. 203209.

PRAT, Ignacio. 1978. «Introducción» a su ed. Poesía modernista española, Madrid, Cupsa Editorial. 
RAYMOND, Marcel. 1960. De Baudelaire al surrealismo (trad. de Juan José Domenchina), Madrid, F.C.E.

RodenBACH, Georges. [1889] s.a. En destierro, trad. esp. de Andrés Guilmain, Madrid, Biblioteca Nueva.

ROSENBLUM, Robert. 1993. La pintura moderna y la tradición del Romanticismo nórdico. De Friedrich a Rothko, Madrid, Alianza Editorial.

SÁNCHEZ OCAÑA, Javier. 1927. «Azorín está escribiendo varias obras superrealistas», Heraldo de Madrid, 21 de abril.

VerHAEREN, Émile. 1887. «Le Symbolisme», L'Art Moderne, 24 de abril; art. Recogido en Impresions, Troisième série, Paris, Mercure de France, 1928, págs. 113-116. 